\title{
ISOLASI DAN SELEKSI BAKTERI PENGHASIL ENZIM EKSTRASELULER PADA TANAH MANGROVE DI PANTAI NOELBAKI
}

\author{
Ermi S. Remijawa ${ }^{1}$, Anggreni D. N. Rupidara ${ }^{1}$, James Ngginak$^{1}$, \\ Ocky Karna Radjasa ${ }^{2}$ \\ ${ }^{1}$ Program Studi Pendidikan Biologi, FKIP, Universitas Kristen Artha \\ Wacana, Kupang, Indonesia \\ ${ }^{2}$ Fakultas Perikanan dan IImu Kelautan, Universitas Diponegoro, \\ Semarang, Indonesia \\ E-mail : jamesngginak@yahoo.com
}

Received April 2020, Accepted August 2020

\begin{abstract}
ABSTRAK
Bakteri yang hidup pada tanah mangrove bersifat halofilik yaitu mampu hidup pada lingkungan dengan kondisi kadar garam yang tinggi. Bakteri yang hidup pada zona yang ekstrim memerlukan protein yang tinggi untuk mempertahankan hidup dan dapat melakukan metabolisme, salah satunya dengan membentuk enzim terutama enzim ekstra seluler (enzim amilase, protease, selulase dan lipase). Tujuannya yaitu untuk mengisolasi dan menyeleksi bakteri penghasil enzim ekstraseluler. Metode yang digunakan adalah survey dan eksperimental terhadap isolasi bakteri dari tanah mangrove yang dikarakterisasi berdasarkan morfologi, pewarnaan gram, dan uji aktivitas enzim amilase dengan media amilum, protease dengan media skim milk, selulase dengan media Carboxy Methyl Cellulosed an lipase dengan media tween 80. Analisis data secara deskriptif kuantitatif. Terdapat tiga parameter yang diukur yaitu suhu, salinitas dan $\mathrm{pH}$. Berdasarkan data penelitian ditemukan bahwa tanah mangrove yang ada di pantai Noelbaki menghasilkan 70 isolat bakteri penghasil enzim ekstra seluler. 33 isolat bakteri memiliki aktifitas enzim amilase, 20 isolat memiliki aktifitas enzim proteolitik, 56 isolat memiliki aktifitas selulolitik,10 isolat memiliki aktifitas lipolitik, sehingga total isolat yang memproduksi enzim ekstraseluler adalah 119 isolat, hal ini menjelaskan bahwa beberapa isolat memiliki kemampuan menghasilkan enzim multi-aktifitas atau mampu menghasilkan beberapa enzim.
\end{abstract}

Kata Kunci : Tanah Mangrove, Bakteri, Enzim Ekstraseluler

ABSTRACT

ISOLATION AND SELECTION OF BACTERIA PRODUCING EXTRACELLULAR ENZYMES ON MANGROVE LAND OF NOELBAKI $B E A C H$. Bacteria living in the halofilic mangrove land are able to live in environments that are high salinity. Bacteria that live in the extreme zone 
require high proteins to sustain life and can metabolize, one by forming enzymes especially extra-cellular enzymes (amilase, protease, selulase and lipase). The aim was to isolate and select extra-cellular enzyme bacteria. This method was a survey and experimental against the insulation of mangrove land controlled by morphology, dyeing grams, and testing for amilase enzyme activity for amilum media, protease with skim milk, selulase with medium carboxy methyl cellulose and lipase in tween media. Quantitative descriptive analysis of data. Three parameters, measured temperature, salinity and ph. Based on research data, were found that mangrove soils located on the coast of noelbaki produced 70 insulations of extreme enzyme yielding bacteria. 33 bacterial isolates have activity in amilase enzyme, 20 isolates have protein activity, 56 isolates had activity cellulase enzyme, 10 isolates had activities lipase enzyme, that include 119 isolates which produced extra-cellular enzymes, which made it clear that some isolates had the ability to create a multi-activity enzyme.

Keywords : Mangrove Land; Bacteria; Extra-cellular Enzymes

\section{PENDAHULUAN}

Indonesia merupakan salah satu negara yang memiliki potensi ekosistem mangrove. Menurut Litbang (2014) ekosistem mangrove tersebar di 17.000 pulau termasuk Nusa Tenggara Timur (NTT) dengan total garis pantai sepanjang $80.000 \mathrm{~km}$. Data dokumen final rencana zonasi wilayah pesisir dan pulau-pulau kecil Provinsi Nusa Tenggara Timur (2017) menjelaskan bahwa NTT memiliki ekosistem mangrove yang sangat potensial yaitu seluas 17.546.52 Ha. Ekosistem mangrove tersebar dibeberapa pesisir pantai termasuk pantai Noelbaki. Pantai ini memiliki luas 10.2 Ha dengan ekosistem mangrove yang melimpah dan masih asri. Kelimpahan ekosistem mangrove dimanfaatkan oleh masyarakat untuk memenuhi kebutuhan hidup (Maximilianus $d k k$., 2015).

Ekosistem mangrove memberikan keuntungan yang cukup besar bagi kehidupan manusia baik dari aspek ekologis maupun aspek ekonomis. Kontribusi ekologis ekosistem mangrove yaitu mampu menahan abrasi pantai, angin topan, tsunami, menjadi tempat tinggal bagi satwa liar, tempat pemijahan ikan dan berperan dalam penyerapan logam berat. Secara ekonomis peran ekosistem mangrove yaitu sebagai salah satu sumber pendapatan masyarakat (Litbang, 2014).

Ekosistem mangrove terletak pada zona intertidal. Daerah atau zona ini memiliki bahan organik dan anorganik yang penting dalam arus energi. Ayu dkk (2017) menyatakan bahwa kelimpahan material pada zona mangrove dipengaruhi oleh aliran air tawar dan air laut sehingga zona ini sangat mendukung kehidupan berbagai organisme laut seperti ikan, crustacea bahkan bakteri. Keberadaan bakteri dalam zona ini berperan sebagai biodegradator atau pengurai. Bakteri dapat ditemukan pada berbagai lokasi atau habitat termasuk di tanah mangrove (Yulma dkk.,2017). Hal ini karena pada zona tersebut bakteri menjalankan peran 
sebagai pengurai serasah akar, batang dan daun serta jasad organisme lain yang mati (Armin dkk., 2014). Bakteri pada zona mangrove cukup beragam yaitu berbentuk basil gram negatif, spiral gram negatif, oval gram positif hingga coccus gram positif (Ayu dkk., 2017). Bakteri hidup dengan kisaran suhu $27^{\circ} \mathrm{C}$ dan bersifat halofilik. Bakteri ini hidup pada lingkungan dengan kondisi kadar garam yang tinggi. Bakteri yang hidup pada zona yang ekstrim memerlukan protein yang tinggi untuk mempertahankan hidup dan dapat melakukan metabolisme. Salah satu cara untuk membantu membentuk protein adalah menghasilkan enzim-enzim yang mendukung eksistensi mikroba.

Enzim yang dihasilkan oleh bakteri pada mangrove adalah proteolitik, amilolitik, selulolitik dan lipolitik (Wilis dan Subagiyo, 2012). Enzim merupakan molekul protein kompleks yang dihasilkan oleh sel hidup dan bekerja sebagai katalisator dalam berbagai proses kimia didalam tubuh. Enzim yang ditemukan dalam mikroorganisme yang hidup di tanah mangrove seperti protease berperan dalam penguraian bahan atau material. Berdasarkan letak dan fungsinya, enzim dibagi menjadi dua yaitu enzim intraseluler dan enzim ekstraseluler. Enzim intraseluler adalah enzim yang disintesis dalam sel-sel hidup dan bekerja di dalam sel sedangkan enzim ekstraseluler adalah enzim yang disintesis dalam sel namun bekerja di luar sel seperti enzim protease, amilase, selulase dan lipase. Enzim-enzim ini dapat diaplikasikan dalam bidang industri yaitu sebagai detergen, kosmetik, makanan, farmasi, tekstil dan proses bioremediasi (Hamza, 2017).

\section{MATERI DAN METODE}

\section{Waktu dan Tempat}

Penelitian ini dilaksanakan pada bulan Juli sampai September 2019. Pengambilan sampel dilakukan di area Pantai Noelbaki, Kabupaten Kupang, Nusa Tenggara Timur (NTT). Pengamatan selanjutnya dilakukan di Laboratorium Mikrobiologi Pendidikan Biologi, Universitas Kristen Artha Wacana Kupang.

\section{Metode Penelitian}

Penelitian ini menggunakan metode survey dan eksperimental dengan pengambilan sampel menggunakan teknik purposive sampling di area mangrove. Parameter yang diukur ada tiga yaitu salinitas, derajat keasaman $(\mathrm{pH})$ dan suhu (Islamiah dkk., 2017)

\section{Prosedur Penelitian}

\section{Pengambilan Sampel}

Pengambilan sampel tanah mangrove dilakukan di Pantai Noelbaki. Sampel tanah diambil menggunakan paralon steril sampai kedalaman 
kurang lebih $10 \mathrm{~cm}$ di dua titik secara acak. Sampel tersebut dimasukkan kedalam plastic ziplock kemudian disimpan dalam coolbox dan dibawa ke Laboratorium Mikrobiologi Pendidikan Biologi UKAW untuk dilakukan penelitian lebih lanjut (Wilis dan Subagiyo, 2012).

\section{Sterilisasi dan Pembuatan Media}

Alat dan bahan disteril menggunakan autoclave dan oven. Sterilisasi pada autoclave menggunakan suhu $121^{\circ} \mathrm{C}$ dengan durasi waktu 2 jam sedangkan pada oven menggunakan suhu $160^{\circ} \mathrm{C}$ dengan waktu 15 menit (Pratiwi, 2008).

Media Zobell $2216 \mathrm{E}$ dan aquades digunakan sebagai media isolasi bakteri. Pembuatan media diawali dengan menimbang 2.94 gram media Zobell 2216 E kemudian dimasukkan kedalam Erlenmeyer ditambah aquades sebanyak $105 \mathrm{~mL}$, selanjutnya dipanaskan menggunakan hotplate dengan magnetic stirrer untuk menghomogenkan media. Media yang sudah homogeny disterilisasi menggunakan autoclave dengan suhu $121^{\circ} \mathrm{C}$ kemudian di tuang kedalam petridish sebanyak 15 mLsampai media tersebut menjadi agar (Wilis dan Subagiyo, 2012).

\section{Isolasi Bakteri}

Diambil 1 gram sampel tanah mangrove dimasukkan kedalam Erlenmeyer dan dilarutkan kedalam $9 \mathrm{~mL}$ aquades kemudian dihomogenkan dengan vortex dan diperoleh pengenceran 10-1, selanjutnya diambil $1 \mathrm{~mL}$ menggunakan mikro pipet steril dan dimasukkan kedalam $9 \mathrm{~mL}$ aquades dan diperoleh pengenceran 10-2. Demikian selanjutnya dilakukan pengenceran hingga pengenceran 10-3, 10-4, 10-5, 10-6, 10-7. Masing-masing seri pengenceran diambil $0,1 \mathrm{~mL}$ menggunakan mikro pipet dan dilakukan penanaman bakteri dengan metode spread plate. Untuk meminimalisir terjadinya kontaminasi maka petridish dilapisi dengan plastic wrap dan inkubasi kurang lebih $2 \times 24$ jam (Islamiah dkk., 2017).

\section{Identifikasi Bakteri}

\section{Pengamatan Makroskopik}

Bakteri yang telah tumbuh diamati karakteristiknya berdasarkan Bergey's Mannual of Determinative Bacteriology yaitu dilihat dari warna, bentuk, tepi dan permukaan koloni bakteri.

\section{Pengamatan Mikroskopik}

Bakteri yang telah diidentifikasi melalui pengamatan makroskopik dilakukan pengamatan lebih lanjut yaitu melakukan pewarnaan gram dengan pengamatan bentuk sel menggunakan mikroskop. Pewarnaan gram dilakukan dengan menggunakan empat larutan yaitu kristal violet, 
iodine, decolorizer dan safranin. Pewarnaan gram diawali dengan mengambil isolate bakteri menggunakan jarum ose kemudian diinokulasikan ke kaca preparat dan ditetesi aquades secukupnya, kemudian dicampur dan diratakan dengan menggunakan ose. Kaca preparat yang telah berisi isolate bakteri kemudian difiksasi ataud ipanaskan di atas Bunsen sesekali sampai aquades hilang atau kering. Tetesi kristal violet kepreparat kemudian ratakan di permukaan preparat. Diamkan selama 60 detik, kemudian bilas dengan aquades dan dikeringkan. Tetesi iodine ke preparat dengan perlakuan yang sama persis dengan kristal violet. Hal ini juga berlaku pada larutan ketiga keempat yaitu, decolorizer dan safranin. Hanya saja pada decolorizer didiamkan selama 30 menit. Preparat kemudian dilihat menggunakan mikroskop untuk mengetahui gram isolate bakteri.

\section{Purifikasi (Pemurnian Bakteri)}

Setelah bakteri tumbuh dilakukan purifikasi dengan menggunakan metode streak plate (goresan). Purifikasi dilakukan dengan mengambil satu koloni Pengambilan koloni ini didasari pada karakterisasi morfologi dari koloni bakteri yaitu berupa bentuk, tepian, permukaan dan warna. Pengambilan bakteri menggunakan jarum ose, kemudian digoreskan pada permukaan media dan dilapisi plastic wrap untuk mencegah kontaminasi, selanjutnya diinkubasi pada suhu $26^{\circ} \mathrm{C}$ sampai bakteri tersebut tumbuh. Ketika bakteri sudah tumbuh, diamati pertumbuhan koloni bakteri apakah telah menjadi kultur murni, jika belum maka dilakukan pemurnian ulang (Sulistiyani dkk., 2015).

\section{Seleksi Bakteri Enzimatik}

Tiap tiap isolate murni diambil menggunakan jarum ose kemudian diinokulasikan ke dalam $5 \mathrm{~mL}$ media cair nutrient broth pada tabung reaksi yang berbeda kemudian diinkubasi di atas shaker pada suhu ruangan selama 24 jam. Menurut Wilis dan Subagiyo (2012) seleksi bakteri enzimatik antara lain:

Uji aktivitas produksi amilase menggunakan media Zobell $2216 \mathrm{E}$ yang diperkaya dengan amilum (1\%). Paper disk steril dimasukkan kedalam tiap-tiap isolat bakteri pada tabung reaksi yang berisi $5 \mathrm{~mL}$ Nutrient Broth kemudian diinokulasikan pada media Nutrient Agar pada petridish dan diinkubasi pada suhu $36^{\circ} \mathrm{C}$ selama 24 jam. Larutan iodine dituang ke atas media kultur dan diamati. Adanya aktivitas produksi enzim amilase ditandai dengan terbentuknya zona jernih di sekitarpaper discdengan latar belakang biru gelap.

Uji aktivitas produksi protease menggunakan media Zobell $2216 \mathrm{E}$ yang ditambah dengan skim milk (1\%) selanjutnya Paper disk steril dimasukkan kedalam tiap-tiap isolat bakteri pada tabung reaksi yang berisi $5 \mathrm{~mL}$ Nutrient Broth kemudian diinokulasikan pada media Nutrient Agar pada petridish dan diinkubasi pada suhu $36^{\circ} \mathrm{C}$ selama 24 jam kemudian 
diamati. Adanya aktivitas enzim protease ditandai dengan adanya zona jernih di sekitar paper disc dengan latar belakang putih.

Uji aktivitas produksi selulase menggunakan media Zobell $2216 \mathrm{E}$ yang di perkaya dengan Carboxy Methyl Cellulose (1\%) selanjutnya paper disk steril dimasukkan kedalam tiap-tiap isolat bakteri pada tabung reaksi yang berisi $5 \mathrm{~mL}$ Nutrient Broth kemudian diinokulasikan pada media Nutrient Agar pada petridish dan diinkubasi pada suhu $36^{\circ} \mathrm{C}$ selama 48 jam kemudian larutan gram iodine dituang keatas media kultur dan diamati. Adanya aktivitas produksi selulase ditandai dengan terbentuknya zona bening di sekitar paper disc dengan latar belakang merah muda.

Uji aktivitas produksi lipase menggunakan media Zobell $2216 \mathrm{E}$ dan aquades ditambah dengan tween 80 (1\%). Paper disk steril dimasukkan kedalam tiap-tiap isolat bakteri pada tabung reaksi yang berisi $5 \mathrm{~mL}$ Nutrient Broth kemudian diinokulasikan pada media Nutrient Agar pada petridish dan diinkubasi pada suhu $36^{\circ} \mathrm{C}$ selama 24 jam dan diamati. Adanya aktivitas enzim lipase ditandai dengan terbentuknya endapan asam lemak yang berwarna putih keruh di sekitar paper disc.

\section{Analisis Data}

Data yang diperoleh disajikan secara deskriptif kuantitatif yaitu deskriptif meliputi karakteristik makroskopis dan mikroskopis serta kuantitatif meliputi uji aktivitas enzim ekstraseluler dari masing-masing bakteri yang berhasil diisolasi dari sumber ekosistem mangrove (Saidah,dkk 2014). Lokasi penelitian dapat dilihat pada Gambar 1.

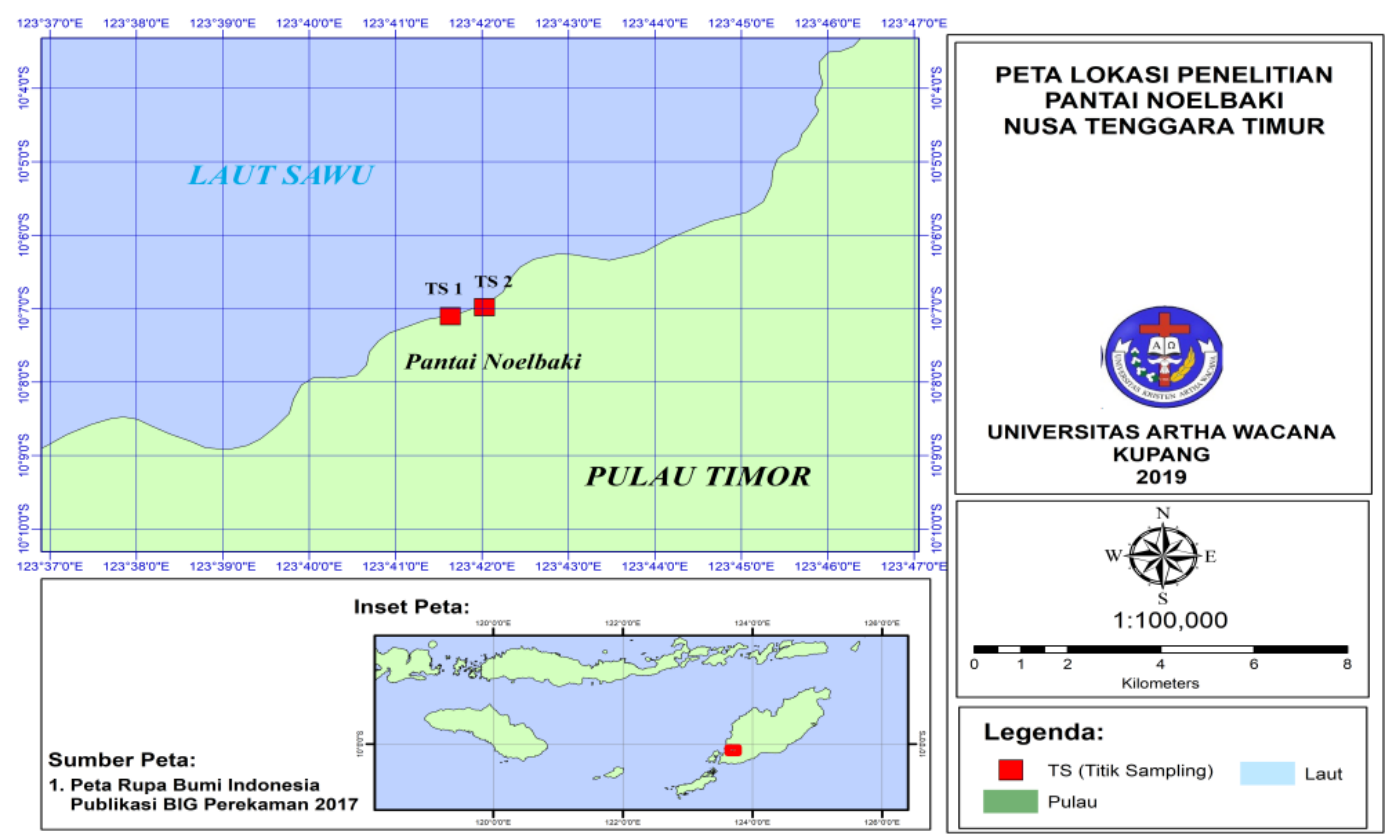

Gambar 1. Peta lokasi penelitian 


\section{HASIL DAN PEMBAHASAN}

\section{Pengukuran Parameter Lingkungan di Lokasi Sampling}

Sampel tanah mangrove diperoleh dari pantai Noelbaki. Pengambilan sampel dilakukan pada dua titik sampling. Kedua titik ini diambil pada zona intertidal yaitu titik pertama terletak pada zona Rhizophora dengan ciri khas akar tanaman mangrove tetap terendam. Zona ini memiliki tanah berlumpur lembek dengan kadar garam lebih rendah sedangkan pada titik kedua pengambilan sampel terletak pada zona Avicennia yaitu pada lapisan paling luar dengan tanah berlumpur lembek dan berkadar garam yang tinggi. Hasil pengukuran parameter lingkungan di lokasi penelitian (titik pertama dan kedua) dapat dilihat pada Tabel 1.

Tabel 1. Parameter lingkungan pada titik sampling

\begin{tabular}{llcc}
\hline \multirow{2}{*}{ Lokasi sampling } & \multicolumn{3}{c}{ Faktor lingkungan } \\
\cline { 2 - 4 } & Suhu & $\mathbf{p H}$ & Salinitas \\
\hline Titik sampling pertama (TS1) & $28^{\circ} \mathrm{C}$ & 8 & $45^{\circ} / \infty$ \\
Titik sampling kedua (TS2) & $26^{\circ} \mathrm{C}$ & 8 & $56^{\circ} / \infty$ \\
\hline
\end{tabular}

Titik sampling pertama $\left(\mathrm{TS}_{1}\right)$ diambil berdekatan dengan laut dan memiliki parameter lingkungan berupa suhu $28^{\circ} \mathrm{C}$, derajat keasaman 8 dan tingkat salinitas $45^{\circ} \%$ sedangkan titik sampling kedua $\left(\mathrm{TS}_{2}\right)$ diambil berdekatan dengan pantai dan memiliki suhu $26^{\circ} \mathrm{C}$, derajat keasaman 8 dan tingkat salinitas $56 \%$. Berdasarkan zona pengambilan sampel, titik sampling kedua $\left(\mathrm{TS}_{2}\right)$ memiliki tingkat salinitas paling tinggi. Hal ini karena sampel diambil pada lapisan paling terluar dari zona intertidal. Menurut Bengen (2003) daerah Avicennia adalah lapisan paling luar yang memiliki salinitas atau kadar garam yang sangat tinggi dibanding dengan zona lainnya. Tingkat keasaman $(\mathrm{pH})$ merupakan salah satu faktor yang sangat mempengaruhi keberadaan unsur hara dalam tanah. Kedua titik sampling memiliki pH yang sama. Menurut Wahyuni (2017) isolat bakteri dapat hidup pada rentang $\mathrm{pH} \mathrm{5,5}$ sampai 8 . Suhu yang diperoleh pada kedua titik sampling tergolong dalam mesofil. Kisaran ini tergolong baik bagi pertumbuhan bakteri. Menurut Fitriani $d k k$ (2005) bakteri mesofil adalah bakteri yang tumbuh pada kisaran suhu antara $20^{\circ} \mathrm{C}$ sampai $45^{\circ} \mathrm{C}$.

Sebelum dilakukan pembuktian enzimatik oleh bakteri tanah mangrove terlebih dahulu dikultur pada media Zobell yang memiliki kadar garam $30 \%$. Biakan isolat tunggal atau murni yang diperoleh dikarakterisasi berdasarkan ciri morfologi. Karakterisasi atau identifikasi jenis bakteri dilakukan dengan mengacu pada buku Bergey's Manual Of Bacteriology (2010). Identifikasi mencakup aspek morfologi seperti warna, bentuk, tepi dan permukaan isolat. Tujuan dari pengujian ini adalah untuk mengetahui kemurnian isolat. Selain itu identifikasi jenis bakteri hasil isolat juga dilakukan melalui pewarnaan. Pewarnaan adalah sebuah metode penentuan jenis bakteri untuk menentukan bakteri gram positif dan negatif. 
Hasil identifikasi morfologi dan pewarnaan gram diperoleh 70 isolat bakteri mangrove. Pada titik sampling pertama $\left(\mathrm{TS}_{1}\right)$ diperoleh 28 isolat sedangkan pada titik sampling kedua (TS2) diperoleh 42 isolat. Hal ini tidak terlepas dari tanah mangrove sebagai media yang berpotensi sebagai tempat tumbuh dan berkembangnya bakteri. Menurut Ayu dkk (2017) hutan mangrove kaya akan bahan organik dan merupakan habitat yang mendukung pertumbuhan bakteri. Distribusi bakteri pada kedua titik sampling berkaitan dengan serasah mangrove, dimana pada TS2 memiliki serasah mangrove lebih banyak dibandingkan dengan TS1.

Identifikasi bakteri pada lokasi penelitian berdasarkan aspek morfologi yang terdiri dari kriteria bentuk, warna, permukaan dan tepi yang sifatnya makroskopis. Sedangkan identifikasi bakteri sifatnya mikroskopis dilakukan berdasarkan pewarnaan gram positi dan gram negatif. Dilihat dari aspek bentuk menunjukkan bahwa bakteri yang berbentuk basil lebih dominan dibandingkan bakteri yang berbentuk coccus pada seluruh isolat. Data menunjukan bahwa diperoleh 53 isolat berbentuk basil dan 17 isolat berbentuk Coccus. Hal ini didukung oleh pendapat Yulma dkk (2017), bahwa bakteri berbentuk basil lebih banyak dibandingkan bentuk lainnya dimana jenis bakteri yang memiliki struktur sel berbentuk basil merupakan bakteri yang resisten terhadap berbagai kondisi sehingga bakteri ini dijumpai hampir disetiap habitat.

Identifikasi secara morfologi bakteri juga dilakukan secara penentuan warna. Warna isolat bakteri yang ditemukan adalah warna putih sebanyak 52 isolat, warna crem sebanyak 5 isolat dan warna kuning sebanyak 3 isolat. Menurut Subagiyo dkk (2017) warna bakteri pada tanah mangrove didominasi oleh warna putih.

Pengamatan bakteri pada tanah mangrove selain secara makroskopis juga dapat dilakukan secara mikroskopis melalui proses pewarnaan. Hasil pewarnaan gram menunjukan terdapat 40 isolat bakteri gram positif dan 30 gram isolat gram negatif. Bakteri gram positif ditandai dengan sel bakteri berwarna ungu. Warna ini disebabkan oleh asam-asam ribonukleat pada sitoplasma sel-sel gram positif membentuk ikatan ungu kristal violet yang kuat dan kompleks sehingga ikatan kimiawi tersebut tidak mudah dipecahkan oleh pemucat warna atau iodine. Reaksi tersebut didasarkan atas perbedaan komposisi kimiawi dinding sel. Sel gram positif mempunyai dinding dengan lapisan peptidoglikan yang tebal sehingga kemampuan untuk mengikat warna kristal violet lebih kuat sedangkan sel bakteri gram negatif memiliki lapisan peptidoglikan yang lebih tipis sehingga kemampuan mengingat warna violet lebih rendah sehingga bakteri gram negatif lebih mengikat warna merah pada safranin. Bakteri gram negatif terlihat berwarna merah hingga merah muda (Nurrochman, 2015).

Berdasarkan karakterisasi morfologi dan uji biokimia isolat bakteri di tanah mangrove maka disimpulkan bahwa jenis bakteri yang ditemukan di lokasi penelitian adalah Escherichia, Pseudomonas dan Bacillus. Menurut Ritonga (2014) bakteri yang teridentifikasi dari serasah mangrove antara lain Pseudomonas, Bacillus, Flavobacterium, Alkaligenes, Sporosarcina, Staphylococcus, Micrococcus, Kurthia, Esherichia, Planococcus dan 
Mycobacterium. Menurut Wilis $d k k$, (2016) bakteri dengan gram positif di duga adalah bakteri yang didominasi oleh bakteri Bacillus.

\section{Uji Aktifitas Enzim Ekstraseluler}

Bakteri yang telah diidentifikasi kemudian dilakukan pengujian enzim ekstraseluler amilase, protease, selulase dan lipase menggunakan media nurient agar ditambah dengan air laut steril yang diperkaya amilum (1\%), skim milk (1\%), CarboxyMethyl Cellulose (1\%) dan tween 80 . Uji aktifitas enzim ekstraseluler dapat dilihat pada Gambar 2 berikut.

Gambar 2. Pengujian aktifitas enzim ekstraseluler
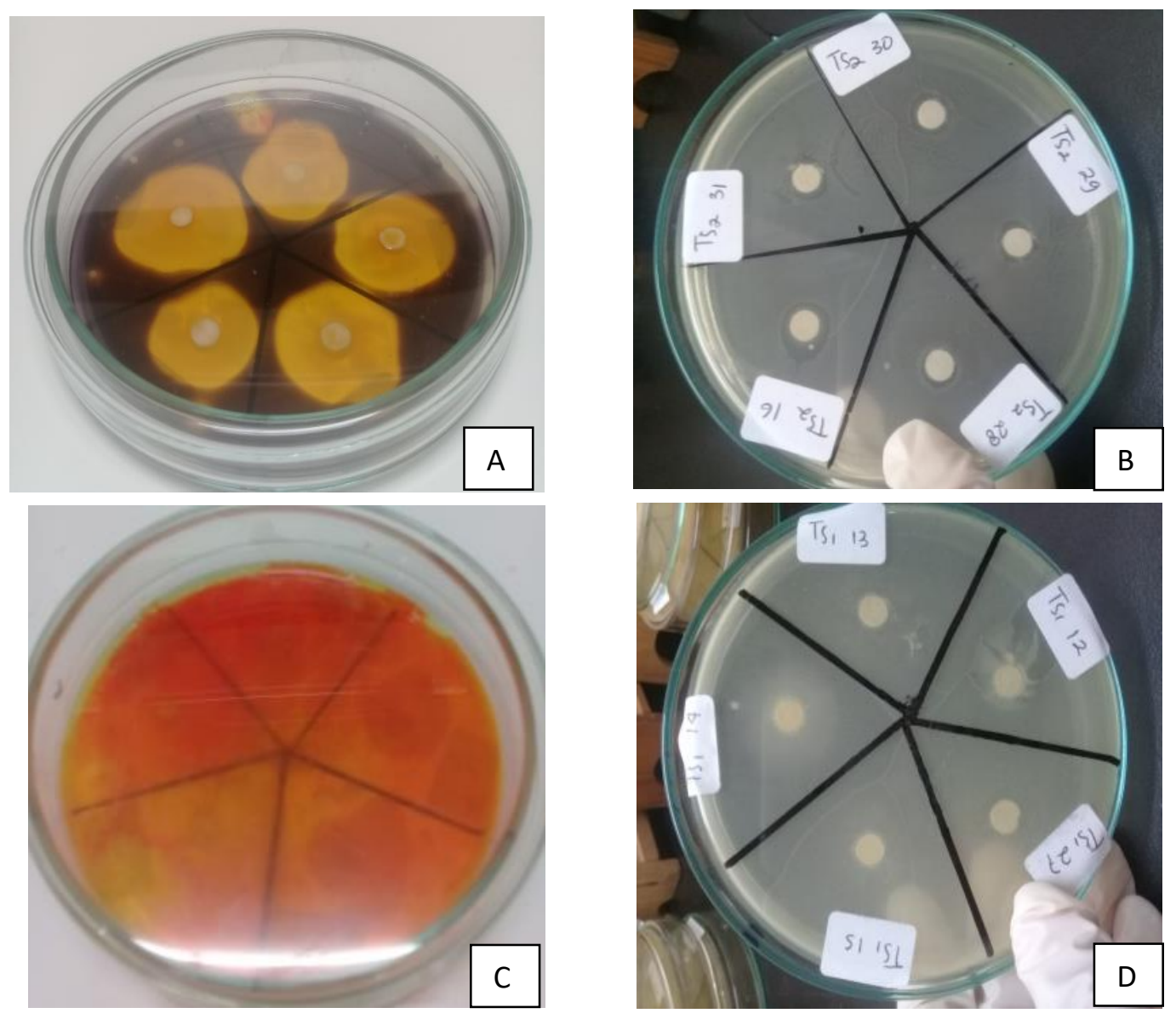

Gambar 2. Uji aktifitas enzim amylase (A), Uji aktifitas enzim protease (B), Uji aktifitas enzim selulase (C), Uji aktifitas enzim lipase (D)

Bakteri yang menghasilkan enzim amilase ditandai dengan reaksi positif warna kuning pada sekitar paperdisk yang berlatar belakang biru gelap. Bakteri yang menghasilkan enzim protease ditandai dengan pembentukan zona bening pada sekitar paperdisk yang berlatar belakang putih. Bakteri yang menghasilkan enzim selulase ditandai dengan pembentukan zona selulolitik pada sekitar paper disk yang berlatar 
belakang kuning kemerahan. Bakteri yang menghasilkan enzim lipase ditandai dengan adanya pembentukan zona lipolitik pada sekitar paper disk dengan latar belakang putih.

Tabel 2. Tabel Pengujian Aktivitas Enzim Ekstraseluler

\begin{tabular}{|c|c|c|c|c|c|}
\hline \multirow{2}{*}{ NO } & \multirow{2}{*}{$\begin{array}{c}\text { KODE } \\
\text { SAMPEL }\end{array}$} & \multicolumn{4}{|c|}{ DIAMETER ZONA BENING (mm) } \\
\hline & & AMILASE & PROTEASE & SELULASE & LIPASE \\
\hline 1 & Bio TS1 01 & $7 \pm 3$ & 0 & $3 \pm 0$ & 0 \\
\hline 2 & Bio TS1 02 & $\begin{array}{l}0 \\
10,6 \pm\end{array}$ & 0 & $1, \overline{3} \pm 1,1$ & 0 \\
\hline 3 & Bio TS1 03 & 10,2 & 0 & $8,4 \pm 6,3$ & 0 \\
\hline 4 & Bio TS1 $05^{a}$ & 0 & 0 & $5 \pm 4,7$ & 0 \\
\hline 5 & Bio TS1 06 & 0 & 0 & $1,4 \pm 1$ & 0 \\
\hline 6 & Bio TS1 09 & $6 \pm 10$ & 0 & $5,2 \pm 8,1$ & $2 \pm 1,2$ \\
\hline 7 & Bio TS1 12 & 0 & $1,4 \pm 1$ & $6,4 \pm 4$ & 0 \\
\hline 8 & Bio TS1 13 & $5 \pm 4,1$ & $1,5 \pm 1,2$ & $10 \pm 7$ & 0 \\
\hline 9 & Bio TS1 14 & 0 & $1,3 \pm 0$ & $4 \pm 2$ & $8 \pm 6$ \\
\hline 10 & Bio TS1 15 & $8 \pm 7,5$ & $2 \pm 1,5$ & $9 \pm 6,5$ & 0 \\
\hline 11 & Bio TS1 16 & 0 & $1,3 \pm 1$ & $8 \pm 0$ & $4 \pm 2$ \\
\hline 12 & Bio TS1 17 & $\begin{array}{l}10 \pm 4 \\
20,3 \pm\end{array}$ & $2 \pm 0$ & $6,1 \pm 3$ & 0 \\
\hline 13 & Bio TS1 18 & $\begin{array}{l}10,7 \\
10,5+8\end{array}$ & 0 & $16 \pm 12$ & $\begin{array}{l}9 \pm 5 \\
104+\end{array}$ \\
\hline 14 & Bio TS1 19 & 2 & 0 & $5,1 \pm 3$ & $\begin{array}{l}8,5 \\
10,5\end{array}$ \\
\hline 15 & Bio TS1 20 & 0 & 0 & $10 \pm 9,1$ & $\pm 4,4$ \\
\hline 16 & Bio TS1 21 & 0 & 0 & $8 \pm 6,1$ & $6 \pm 4$ \\
\hline 17 & Bio TS1 22 & 0 & $1,3 \pm 0$ & $17,1 \pm 10$ & 0 \\
\hline 18 & Bio TS1 23 & 0 & $1 \pm 3$ & $11,3 \pm 9,6$ & 0 \\
\hline 19 & Bio TS1 25 & $\begin{array}{l}10,4 \pm 8 \\
10,5 \pm\end{array}$ & $1 \pm 0$ & $12,6 \pm 10$ & 0 \\
\hline 20 & Bio TS1 26 & 10,3 & $1,4 \pm 0,7$ & $11,3 \pm 6$ & 0 \\
\hline 21 & Bio TS1 27 & $0,8 \pm 0,6$ & $2 \pm 1,3$ & $8 \pm 3,4$ & 0 \\
\hline 22 & Bio TS1 $22^{a}$ & 0 & 0 & $8,2 \pm 6,1$ & $8 \pm 5$ \\
\hline 23 & Bio TS1 28 & $8 \pm 7$ & 0 & $4 \pm 1,5$ & 0 \\
\hline 24 & Bio TS1 30 & $\begin{array}{l}6 \pm 5 \\
10,4 \pm\end{array}$ & 0 & $2,3 \pm 1,4$ & 0 \\
\hline 25 & Bio TS1 31 & 9,5 & 0 & $2,2 \pm 0,5$ & 0 \\
\hline 26 & Bio TS1 33 & 0 & 0 & $1,3 \pm 0$ & 0 \\
\hline 27 & Bio TS1 $05^{b}$ & $\begin{array}{l}9 \pm 8 \\
10,3 \pm\end{array}$ & $3 \pm 1$ & $6,2 \pm 3,1$ & 0 \\
\hline 28 & Bio TS1 $14^{a}$ & 8,2 & 0 & $26,1 \pm 25,2$ & 0 \\
\hline 29 & Bio TS2 02 & 0 & $1,4 \pm 1$ & $5 \pm 2,1$ & 0 \\
\hline 30 & Bio TS2 03 & 0 & 0 & $0,2 \pm 0,1$ & 0 \\
\hline 31 & Bio TS2 04 & $5 \pm 1,3$ & $1,5 \pm 1$ & $4 \pm 1,1$ & 0 \\
\hline 32 & Bio TS2 05 & $7 \pm 4$ & 0 & $17,1 \pm 11,1$ & 0 \\
\hline 33 & Bio TS2 07 & 0 & 0 & 0 & 0 \\
\hline
\end{tabular}




\begin{tabular}{|c|c|c|c|c|c|}
\hline \multirow{2}{*}{ NO } & \multirow{2}{*}{$\begin{array}{c}\text { KODE } \\
\text { SAMPEL }\end{array}$} & \multicolumn{4}{|c|}{ DIAMETER ZONA BENING (mm) } \\
\hline & & AMILASE & PROTEASE & SELULASE & LIPASE \\
\hline 34 & Bio TS2 08 & $5 \pm 3$ & 0 & 0 & 0 \\
\hline 35 & Bio TS2 $08^{a}$ & 0 & 0 & 0 & 0 \\
\hline 36 & Bio TS2 09 & 0 & 0 & $0,1 \pm 0$ & 0 \\
\hline 37 & Bio TS2 $10^{a}$ & 0 & 0 & 0 & 0 \\
\hline 38 & Bio TS2 $10^{b}$ & 0 & 0 & $1 \pm 0,1$ & $2 \pm 1,5$ \\
\hline 39 & Bio TS2 12 & 0 & 0 & $0,2 \pm 0$ & 0 \\
\hline 40 & Bio TS2 13 & 0 & 0 & $2 \pm 1,1$ & 0 \\
\hline 41 & Bio TS2 14 & $5 \pm 4$ & 0 & $1,1 \pm 0$ & 0 \\
\hline 42 & Bio TS2 15 & 0 & 0 & 0 & 0 \\
\hline 43 & Bio TS2 16 & 0 & $2 \pm 1,4$ & $6,1 \pm 5,1$ & 0 \\
\hline 44 & Bio TS2 17 & 0 & 0 & 0 & 0 \\
\hline 45 & Bio TS2 19 & $8 \pm 6,4$ & 0 & $3 \pm 2$ & 0 \\
\hline 46 & Bio TS2 $10^{c}$ & $\begin{array}{l}0 \\
10,4 \pm\end{array}$ & 0 & $13,1 \pm 7,1$ & 0 \\
\hline 47 & Bio TS2 $13^{a}$ & 6,3 & 0 & $8,1 \pm 4,1$ & 0 \\
\hline 48 & Bio TS2 22 & $10,3 \pm 8,4$ & 0 & $8 \pm 4$ & 0 \\
\hline 49 & Bio TS2 23 & $10,3 \pm 9,5$ & 0 & $5,1 \pm 3$ & 0 \\
\hline 50 & Bio TS2 $23^{a}$ & $10,6 \pm 6,5$ & 0 & $6,1 \pm 4,1$ & 0 \\
\hline 51 & Bio TS2 24 & 0 & 0 & 0 & 0 \\
\hline 52 & Bio TS2 27 & 0 & 0 & $1,1 \pm 0$ & 0 \\
\hline 53 & Bio TS2 28 & 0 & 0 & $2,1 \pm 1$ & 0 \\
\hline 54 & Bio TS2 29 & 0 & 0 & $7,1 \pm 4,1$ & 0 \\
\hline 55 & Bio TS2 30 & 0 & $3 \pm 1$ & $5 \pm 2,1$ & 0 \\
\hline 56 & Bio TS2 31 & 0 & $2 \pm 1$ & $5,1 \pm 3,1$ & 0 \\
\hline 57 & Bio TS2 32 & 0 & $1,3 \pm 1$ & 0 & 0 \\
\hline 58 & Bio TS2 33 & $10,6 \pm 6,5$ & 0 & $16,1 \pm 11$ & 0 \\
\hline 59 & Bio TS2 34 & $10,5 \pm 7,6$ & $3 \pm 2$ & $5 \pm 4,2$ & 0 \\
\hline 60 & Bio TS2 37 & $7 \pm 4$ & 0 & $8 \pm 6$ & 0 \\
\hline 61 & Bio TS2 38 & $3 \pm 4$ & 0 & 0 & 0 \\
\hline 62 & Bio TS2 40 & $10,6 \pm 5,3$ & 0 & 0 & 0 \\
\hline 63 & Bio TS2 41 & $4 \pm 2$ & 0 & 0 & 0 \\
\hline 64 & Bio TS2 42 & $5 \pm 4$ & 0 & 0 & 0 \\
\hline 65 & Bio TS2 $03^{a}$ & $10,1 \pm 7,1$ & 0 & 0 & 0 \\
\hline 66 & Bio TS2 $22^{a}$ & 0 & 0 & $25 \pm 5$ & 0 \\
\hline 67 & Bio TS2 32 a & $8 \pm 6$ & 0 & 0 & 0 \\
\hline 68 & Bio TS2 $23^{a}$ & 0 & $10 \pm 8,3$ & $2,6 \pm 1,2$ & $8 \pm 4,5$ \\
\hline 69 & Bio TS2 $22^{b}$ & 0 & 0 & $16 \pm 12,1$ & 0 \\
\hline 70 & Bio TS2 $19^{a}$ & 0 & 0 & $10 \pm 0$ & 0 \\
\hline Kete & $\begin{aligned} \text { angan : } & \text { Bio TS1 } \\
& ++ \\
& \text { Bio TS2 } \\
& +++ \\
& + \\
& -\end{aligned}$ & $\begin{array}{l}=\text { Positi } \\
=\text { Biolos } \\
=\text { Positi } \\
=\text { Positi } \\
=\text { Nega }\end{array}$ & $\begin{array}{l}\text { titik sampling } \\
\text { sedang }(6-10 \\
\text { titik sampling } \\
\text { tinggi( } 11-30 \text { m } \\
\text { rendah }(1-5,9\end{array}$ & $\begin{array}{l}\text { oertama } \\
\text { gmm) } \\
\text { kedua } \\
\text { n) } \\
\text { nm) }\end{array}$ & \\
\hline
\end{tabular}


Berdasarkan Tabel 2, seleksi bakteri yang ditemukan di TS1 terdapat 16 isolat yang menghasilkan enzim amilase, untuk TS2 terdapat 18 isolat menghasilkan enzim amilase sehingga total isolat yang menghasilkan enzim amilase sebanyak 33 isolat. Menurut Susilawati $d k k$, (2015) bakteri amilolitik ditanah sangat melimpah karena tanah banyak mengandung amilum. Kemampuan suatu bakteri dalam menghasilkan enzim amilase ditunjukkan dengan reaksi positif pada sekitar paperdish berupa pembentukan zona hidrolitik pada media uji serta latar belakang warna biru gelap. Pembentukan zona hidrolitik paling tinggi dalam pengujian enzim amilase terdapat pada kode isolat TS1 18 dengan diameter aktifitas amilolitik sebesar $20,3 \mathrm{~mm}$. Pembentukan zona amilolitik pada isolat bakteri penghasil enzim amilase menunjukkan bahwa amilum $1 \%$ pada media dihidrolisis oleh enzim amilase menjadi senyawa sederhana seperti maltosa, dekstrin dan glukosa. Untuk melihat lebih jelas adanya zona amilolitik pada media amilum 1\% maka media tersebut ditetesi larutan lugol's iodine. Daerah di luar zona amilolitik akan berwarna biru keunguan setelah diberi larutan tersebut, hal ini karena larutan lugol's iodine yang bereaksi dengan amilum tidak terhidrolisis. Daerah zona amilolitik berwarna kuning karena amilum yang terdapat pada zona tersebut terhidrolisis menjadi senyawa yang lebih sederhana seperti disakarida atau monosakarida (Susilawati $d k k, 2015)$.

Kemampuan menghasilkan enzim amilase pada bakteri enzimatik merupakan aktivitas yang berkaitan dengan kemampuan menghasilkan karbohidrat. Beberapa jenis karbohidrat diantaranya adalah maltose, sukrosa, glukosa dan galaktosa. Penambahan karbohidrat berupa amilum berpengaruh baik untuk produksi enzim amilase. Menurut Purnawan $d k k$ (2015) penambahan glukosa sebagai sumber nutrisi untuk bakteri laut penghasil enzim amilase menunjukkan titik optimum paling tertinggi dibandingkan dengan sumber karbohidrat lainnya. Glukosa sangat berperan dalam meningkatkan pertumbuhan sel bakteri penghasil enzim amilase.

Seleksi bakteri yang ditemukan di TS1 terdapat 20 isolat yang menghasilkan enzim protease, untuk TS2 terdapat 8 isolat menghasilkan enzim protease sehingga total isolat yang menghasilkan enzim protease sebanyak 28 isolat. Pembentukan zona aktivitas proteolitik tertinggi dalam pengujian enzim protease terdapat pada kode isolat TS2 $23^{\mathrm{a}}$ dengan diameter zona proteolitik sebesar $10 \mathrm{~mm}$. Kemampuan menghasilkan enzim protease dengan pembentukan zona proteolitik yang ditandai dengan hidrolisis skim milk. Media skim milk agar memiliki kandungan protein yang akan dipecah oleh mikroorganisme proteolitik menjadi senyawa nitrogen terlarut sehingga pada koloni dikelilingi area bening (Fatoni $d k k, 2008$ ).

Kemampuan bakteri untuk menghasil enzim protease berkaitan dengan pemecahan molekul protein. Molekul protein dipecah menjadi senyawa lebih sederhana sehingga menjadi nutrisi bagi pertumbuhan sel bakteri. Menurut Islamiah $d k k$, (2018) bakteri penghasil enzim protease adalah bakteri yang mampu mendegradasi protein dan memproduksi enzim protease ekstraseluler. 
Seleksi bakteri yang ditemukan di TS1 terdapat 28 isolat yang menghasilkan enzim selulase, untuk TS2 terdapat 28 isolat menghasilkan enzim selulase sehingga total isolat yang menghasilkan enzim selulase sebanyak 56 isolat. Aktifitas bakteri enzimatik didominasi oleh bakteri penghasil enzim selulase, karena proses sampling dilakukan tepat dibawah pohon mangrove. Tumbuhan pada prinsipnya menghasilkan selulosa sehingga dengan demikian tidak menutup kemungkinan produksi enzim selulase oleh isolat bakteri menjadi signifikan. Menurut Reanida (2012) daun yang gugur menyebabkan bakteri pendegradasi yang menguraikan selulase. Pembentukan zona selulolitik yang tertinggi ditemukan pada kode isolat TS1 $14^{\mathrm{a}}$ dengan diameter zona aktivitas selulolitik sebesar $26,1 \mathrm{~mm}$. Terbentuknya zona selulolitik pada sekitar koloni disebabkan oleh potensi isolat bakteri penghasil enzim selulase dalam mendegradasi selulosa pada media agar Carboxy Methyl Cellulose. Pembentukan warna merah dan kuning di luar zona selulolitik disebabkan oleh tidak terhidrolisisnya selulosa oleh bakteri pengasil enzim selulase, sedangkan daerah zona selulolitik tidak berwarna disebabkan oleh terhidrolisnya selulosa oleh bakteri pendegradasi selulase. Menurut Fikrinda (2000) aktivitas sekresi enzim selulase ditandai dengan pembentukan diameter zona selulolitik pada media agar Carboxy Methyl Cellulose.

Kemampuan bakteri menghasilkan enzim selulase berkaitan dengan kemampuan aktivitas bakteri mendegradasi selulosa. Selulosa diubah menjadi senyawa yang lebih sederhana sehingga bakteri mendapatkan nutrisi dari senyawa sederhana tersebut untuk pertumbuhan sel bakteri. Menurut Seprianto (2017) sumber selulosa yang berasal dari lingkungan yaitu serasah dimanfaatkan oleh bakteri penghasil enzim selulase untuk mendapatkan nutrisi bagi pertumbuhan sel bakteri.

Seleksi bakteri yang ditemukan di TS1 terdapat 8 isolat yang menghasilkan enzim lipase, untuk TS2 terdapat 2 isolat menghasilkan enzim lipase sehingga total isolat yang menghasilkan enzim lipase sebanyak 10 isolat. Aktifitas bakteri penghasil enzim lipase merupakan penghasil enzim terendah dibandingkan dengan aktifitas enzim amilase, protease dan selulase. Perlu diketahui bahwa produksi enzim lipase sangat dipengaruhi oleh $\mathrm{pH}$ dan kadar garam. Derajat keasaman pada kedua titik sampling adalah 8 , hal ini menyebabkan enzim lipase kurang bekerja dengan optimal pada tanah mangrove, selain itu enzim lipase yang dihasilkan oleh bakteri digunakan dalam menyesuaikan diri dengan kondisi lingkungan seperti tekanan osmotik. Menurut Indah dkk (2017) pH optimal untuk aktifitas enzim lipase pada mikroba adalah 7. Jika pH lebih rendah atau lebih tinggi akan memungkinkan terjadinya denaturasi atau hilangnya struktur senyawa protein atau asam nukleat. Pembentukan zona keruh paling tinggi pada pengujian enzim lipase ditemukan pada kode isolat TS1 15 dengan diameter zona lipolitik sebesar 10,5 mm. Terbentuknya zona lipolitik disekitar koloni disebabkan oleh bakteri yang memiliki potensi menghidrolisis nutrisi pada media. Media yang digunakan untuk pengujian enzim lipase adalah tween 80, dimana media ini merupakan salah satu nutrisi yang baik bagi bakteri lipolitik. Menurut 
Gupta (2004) faktor utama yang mempengaruhi produksi lipase adalah sumber karbon dari bakteri tersebut. Umumnya, lipase akan diproduksi oleh bakteri jika tersedia sumber nutrisi yakni karbon yang dipecah dari senyawa lipid. Lipid tersebut dapat berupa minyak, trialsigliserol, asam lemak, ester yang dapat terhidrolisis, tweens dan gliserol.

Berdasarkan zona aktivitas enzim yang tertinggi maka isolat bakteri yang memiliki kriteria yang sesuai berturut-turut yaitu isolat TS1 $14^{\mathrm{a}}$ (Selulase), isolat TS1 18 (Amilase), isolat TS1 15 (Lipase), isolat TS2 $23^{\mathrm{a}}$ (Protease). Beberapa bakteri memiliki kemampuan multiaktifitas atau dengan kata lain dapat atau mampu menghasilkan beberapa enzim. Kode isolat yang mampu menghasilkan enzim amilase, protease dan selulosa yaitu TS1 dengan 7 isolat yang terdiri dari TS1 08, 10, 12, 19, 20, 21 dan 27 sedangkan Pada TS2 diperoleh 2 isolat yaitu TS2 03 dan 32 . Kode isolat yamg mampu menghasilkan protease, selulase dan lipase adalah TS1 09 dan 11. Menurut Wilis dan Subagiyo (2012) bakteri yang diisolasi dari mangrove rembang memiliki kemampuan multiaktifitas amilolitik, proteolitik dan selulolitik. Suatu isolat bakteri memiliki kemampuan multiaktifitas disebabkan oleh kondisi lingkungan yang sangat ekstrim, seperti kadar garam yang sangat tinggi sehingga menyebabkan bakteri berusaha beradaptasi dengan cara memproduksi beberapa enzim. Enzim ini dipakai oleh bakteri untuk pertahanan hidup.

\section{KESIMPULAN}

Tanah mangrove yang ada di pantai Noelbaki menghasilkan 70 isolat bakteri penghasil enzim ekstra seluler. 33 isolat bakteri memiliki aktifitas amilase dengan diameter zona amilolitik tertinggi terdapat pada kode isolat TS1 18 sebesar $20,3 \mathrm{~mm}, 20$ isolat bakteri memiliki aktifitas protease dengan diameter zona proteolitik tertinggi terdapat pada kode isolat TS223a sebesar $10 \mathrm{~mm}, 56$ isolat bakteri memiliki aktifitas selulase dengan diameter zona selulolitik tertinggi terdapat pada kode isolat TS1 14a sebesar $26,1 \mathrm{~mm}, 10$ isolat bakteri memiliki aktifitas lipase dengan diameter zona lipolitik tertinggi terdapat pada kode isolat TS1 15 sebesar $10,5 \mathrm{~mm}$. Beberapa bakteri memliki kemampuan multiaktifitas yaitu bakteri yang mampu menghasilkan beberapa enzim. Kode isolat yang mampu menghasilkan enzim amilase, protease dans elulosa yaitu TS1 dengan 7 isolat yang terdiri dari TS1 08, 10, 12, 19, 20, 21 dan 27 sedangkan Pada TS2 diperoleh 2 isolat yaitu TS2 03 dan 32 . Kode isolat yamg mampu menghasilkan protease, selulase dan lipase adalah TS1 09 dan 11. Berdasarkan kemampuan itu diduga jenis bakteri yang ada adalah jenis Bacillus dan Pseudomonas. 


\section{DAFTAR PUSTAKA}

Armin N.,Wardah., Yusran. 2014.Sifat Kimia Tanah Pada Berbagai Zonasi Hutan Mangrove Di DesaTumpapa Kecamatan Balinggi Kabupaten Parigi Moutong. Warta Rimba. No 3(1): 17-23.

Ayu K.D., Lisna M., Rolan R. 2017. Isolasi Bakteri Dari Tanah Mangrove Rhizopora Sp. Di Kota Bontang. Proceeding Of The 5th Mulawarman Pharmaceuticals Conferences. Fakultas Farmasi Universitas Mulawarman. Samarinda.

Bengen D.G 2003. Pedoman Teknis: Pengenalan Dan Pengelolaan Ekosistem Mangrove.PKSPL.IPB. Bogor.

Bergey's Manual Of Systematic Microbiology. 2010. The Bacteriodetes, Spirochaetes, Tenericutes (Mollicutes), Acidobacteria, Fibrobacteres, Fusobacteres, Dictyoglomi, Gemmatimonadetes, Lentisphaerae, Verrucomicrobia, Chlamydiae And Planctomycetes. Department Of Microbiology 527 Biological Sciences Building. University Of Georgia Athens, GA 30602-2605. USA.

Dokumen Final Rencana Zonasi Wilayah Pesisir Dan Pulau-Pulau Kecil Provinsi Nusa Tenggara Timur. 2017.

Fatoni, A.Z ., Puji. .. 2008. "Isolasi Dan Karakterisasi Protease Ekstraseluler Dari Bakteri."

Final, Dokumen. 2017. "Dokumen Final Rencana Zonasi Wilayah Pesisir Dan Pulau-Pulau Kecil Provinsi Nusa Tenggara Timur."

Fikrinda, I. Anas, T. Purwadaria dan D. A. Santosa. 2000. Isolasi dan Seleksi Bakteri Penghasil Selulase Ektremofil dari Ekosistem Air Hitam. Jurnal Mikrobiologi Indonesia, 5(2) : 48-50.

Fitriani H., Rahman N., Kurniawati S., Aryaningrum, P .D., Hartati N. S. 2019. Karakteristik Protoplas Mesofil Daun Dari Beberapa Genotype Ubi Kayu (Manihot Esculenta Crantz). Journal Biopropal Industri. Vol 10 (1) 1-13.

Gupta R., N. Gupta dan P. Rathi 2004. Bacterial lipases: an overview of production, purification and biochemical properties. Microbiol technol. Vol 64: 763-781.

Hamza, T. A. 2017. Bacterial Protease Enzyme: Safe And Good Alternative For Industrial And Commercial Use. Int.J. Chem. Biomol. Sci. Vol 3(1):1-10. 
Indah, Mappiratu, Musafira. 2017.Produksi Enzim Lipase Dari Aspergillus Niger Isolat Kapang Kopra Dengan Menggunakan Medium Kelapa Parut. Jurnal riset kima.(3):269-276.

Islamiah, Dwi Nur, Riza Linda, and Rahmawati. 2017. "Jenis-Jenis Bakteri Rizosfer Kawasan Tanah Mangrove Avicennia Di Kelurahan Terusan, Kecamatan Mempawah Hilir, Kalimantan Barat." Jurnal Protobiont 6(3):165-72.

Litbang Kehutanan. 2014. Pengelolaan Hutan Mangrove Dan Ekosistem Pantai. Sistesis Rpi. Halaman 284-296.

Maximilianus A., Leonardus B., Eduardus J. E. 2015. Struktur Vertikal Komunitas Mangrove di Pantai Noelbaki, Kupang Tengah, Kupang. $\mathrm{Http} / /$ Repository.Unwira.Ac.Id/Id/Eprint/433.

Nurrochman, Fajar. 2015. "Eksplorasi Bakteri Selulolitik Dari Tanah Hutan Mangrove Baros Kretek, Bantul, Yogyakarta." Naskah Publikasi.

Pratiwi S. T. 2008. Mikrobiologi Farmasi.Jakarta: Erlangga.

Purnawan, A., Y. Capriyanti, PA. Kurniatin, N. Rahmani, \& Yopi. 2015. Optimasi Produksi Enzim Amilase dari Bakteri Laut Jakarta Arthrobacter arilaitensis. Jurnal Biologi Indonesia.

Reanida, Pramita Putri, Agus Supriyanto dan Salamun. 2012. "Eksplorasi Bakteri Selulolitik Dari Tanah Mangrove Wonorejo Surabaya". Universitas Airlangga: Surabaya.

Ritonga, D.R. 2014. Keanekaragaman Bakteri Serasah Daun Rhizophora apiculata Yang Mengalami Dekomposisi Pada Berbagai Tingkat Salinitas Di Kota Pari Pantai Cermin Sumatera Utara. [Tesis] Program Pascasarjana. Universitas Sumatera Utara.

Saidah, Afif N. 2014. "Isolasi Bakteri Proteolitik Termofilik Dari Sumber Air Panas Pacet Mojokerto Dan Penguji Aktivitas Enzim Protease." Skripsi.

Seprianto. (2017). Isolasi dan penapisan bakteri selulolitik dari berbagai jenis tanah sebagai penghasil enzim selulase. Indonesian Journal of Biotechnology and Biodiversity, 1(2), 64-70.

Subagiyo., Muhammad S. R. D., Wilis A.S. 2017. Potensi Ekosistem Mangrove Sebagai Sumber Bakteri Untuk Produksi Protease, Amilase Dan Selulase. Jurnal Kelautan Tropis. Vol. 20(2):106111.(ISSN 0853-7291). 
Sulistiyani., Wahjono H., Radjasa O.K., Sabdono A., Khoeri M. .. and Karyana E. 2015. "Antimycobacterial Activities From Seagrass Enhalus Sp. Associated Bacteria Against Multi Drug Resistance Tuberculosis (MDR TB) Bacteria." Procedia Environmental Sciences 23:253-59.

Susilawati, Ika Oksi, Ummi Mardhiah Batubara, and Hesti Riany. 2015. "Analisis Aktivitas Enzim Amilase Yang Berasal Dari Bakteri Tanah Di Kawasan Universitas Jambi." Semirata 4(1):359-67.

Wahyuni, E. A. 2017. Karakteristik Ph Dan Pengaruhnya Terhadap Bakteri Coliform Di Perairan Selat Madura Kabupaten Pamekasan. Journal Depik. Vol 6(3) 214-220.

Wills A. S. dan Subagiyo. 2012. Isolasi dan Seleksi Bakteri Penghasil Enzim Ekstraseluler (proteolitik , amilolitik , lipolitik dan selulolitik) yang Berasal dari Sedimen Kawasan Mangrove. Jurnal ilmu kelautan. Vol.17(3): 164-168 (ISSN 0853-729).

Yulma., Burhanudin I., Sunarti., Eka M., Neni W., Mursyiban. 2017. Identifikasi Bakteri Pada Serasah Daun Mangrove Yang Terdekomposisi Di Kawasan Konservasi Mangrove Dan Bekantan Kota Tarakan. Jurnal Of Tropical Biodiversity And Biotechnology (2): 28-33. 